\title{
A FUNÇÃO SOCIAL DA EMPRESA $V S$ A FUNÇÃO SOCIAL DA PROPRIEDADE - ESGOTAMENTO E SATISFAÇÃO DO DIREITO DE PROPRIEDADE NA ATUAÇÃO DO EMPRESÁRIO?
}

MENDONÇA, João Josué Walmor de ${ }^{1}$

Recebido em: 2008-01-15

Aprovado em: 2009-04-06

ISSUE DOI: $10.3738 / 1982.2278 .159$

RESUMO: O presente trabalho tem como finalidade discorrer sobre a função social da empresa. Será a função social da empresa a mesma que a função social da propriedade? A propriedade dos meios de produção tem relevo e importância quando se insere no âmbito do direito de empresa, direito comercial. E, sob este enfoque é que se analisa a propriedade, no ponto, a função social da propriedade no direito de empresa. E, é a propriedade, ou os institutos jurídicos, é que são determinantes para afirmar as posições econômicas, e não o contrário. A economia não deve e não pode determinar o conteúdo da função social da empresa, ou mesmo da propriedade. Deste modo, creia-se que a propriedade, ou a empresa, dos meios de produção tem um fim que não é o fim voltado por e em si mesma. Deve atender a sua função social. A função social estabelecida no ordenamento jurídico e não no ordenamento econômico. É neste sentido que se discorre sobre este polêmico instituto, não puramente uma discussão acadêmica, mas com finalidade de utilizar o resultado no social.

Palavras-chave: Direito Constitucional. Direito Civil. Direito Comercial. Função social.

\section{THE SOCIAL FUNCTION OF THE COMPANY VS THE FUNCTION OF SOCIAL PROPERTY - EXHAUSTION AND SATISFACTION OF THE LAW OF PROPERTY IN ACTION OF THE ENTREPRENEUR?}

SUMMARY: This paper aims to discuss the social function of the company. Is the function of the company the same as the social function of property? The ownership of the means of production has important significance when it falls under the business's law, commercial law. Under this approach is that it examines the property at the point, the social function of property rights of the company. Of the property, or the legal institutions, that are crucial to affirm the economic positions, and not inverse. The economy should not and cannot determine the content of the social function of the company, or even the property. Thus, believe that the property, or the company, means of production has an order that is not the end turned in and by it. Consider to realize the social function. The social function established in the law and not on economic planning. It is in this sense it is about this controversial institute, not a purely academic discussion, but with purpose to use the result in the company.

Keyword: Constitucional Law. Civil Law. Commercial Law. Social function. Advogado. Inscrito na 70 ${ }^{\mathrm{a}}$ Subsecção da OABSP. Graduado pela Faculdade de Direito da
Universidade de Franca - UNIFRAN. Texto redigido em junho-2008. 


\section{INTRODUÇÃO}

As transformações sociais, o progresso científico, a prevalência da informação, a guerra tecnológica, o rompimento de barreiras geográficas. $\mathrm{O}$ mundo passa por transformações incalculáveis, inumeráveis. Pode-se apontar algumas evoluções, progressos, avanços, descobertas.

A atividade empresarial depende, em muito, dos contornos econômicos e jurídicos para atuar, desenvolver. Sejam nos atos próprios de empresa, nos atos concernentes aos fins e anseios sociais, quando postos, estes dois atos, insertos, no direito de empresa. A empresa deve atender os anseios de política econômica e de política social? A atividade empresarial é unicamente para satisfazer os anseios do empresário? Qual a importância da propriedade no seio da empresa e quais as dimensões que adquire no mundo moderno?

Tais questões estão ainda hoje com respostas tímidas e bastante tendenciosas. Conforme o item 5.1, o posicionamento doutrinário trazido por Franco (2008, p. 129), das lições de Gallo e Iudica, demonstram quão é controvertida a questão da função social da empresa.

Há, conforme estas doutrinas, o que se entende por funcionalização da empresa, com reflexos de interesses no âmbito privado e público. O interesse empresarial e social deverá ou não atender os ditames do Poder Público.

Desta forma, o trabalho foi estruturado em um ambiente científico de mudança ${ }^{2}$, verifica-se que estas são para correr e forçar uma adaptação ao mundo dos fatos. $\mathrm{O}$ direito é experiência. A experiência jurídica é uma experiência normativa, conforme diz Bobbio (2001, p. 23), mas não se deve utilizar apenas das normas, pois a mudança e as necessidades sociais são maiores que as normas.

\section{FUNÇÃO SOCIAL DA PROPRIEDADE}

A propriedade espelha um direito. É direito real, pois a pessoa exerce sobre a coisa. O conceito e a compreensão, até atingir a concepção moderna de propriedade

\footnotetext{
2 Leia-se crise. Mudança, inovação, conceitos propostos por Bentham (2002, p. 276): "Mudança é um termo neutro, quero dizer, que não encerra nem bem nem mal, e que simplesmente exprime um fato. Inovação é uma voz vituperável, que além de idéia de mudança apresenta ao espírito o antecipado juízo de que esta outra de que se trata encerra um mal ou perigo. Quanto mais acessíveis somos as impressões que resultam da linguagem vulgar, tanto mais dispostos estados a dar acolhimento a este sofisma; inovação toma-se sinônimo de transtorno e anarquia; a imaginação invoca espectros; e já não pode obrar a razão". Quanto aos paradigmas da estabilidade na teoria científica, Tavares (2003, p. 3-4).
} 
privada, sofrem inúmeras influências e transformações no curso da história dos vários povos, desde a antiguidade. A história da propriedade é decorrência direta da organização política (VENOSA, 2003, p. 151, v. 5).

Para esse civilista (VENOSA, 2003, p. 155, v. 5), a propriedade determina a estrutura econômica e social dos Estados. Sob perspectiva constitucional, Silva Neto (2001, p. 107) diz:

$\mathrm{O}$ art. $5^{\circ}, \mathrm{XXII}$ ("é garantido o direito de propriedade"), muito mais do que salvaguardar o direito fundamental de propriedade, é um dos enunciados declarativos do modelo econômico abraçado pelo constituinte originário: o capitalista.

O modelo econômico pátrio é o capitalismo liberal, sendo imperativo que o modelo jurídico, do ordenamento jurídico seja conforme as leis econômicas e os interesses econômicos praticados.

E observe-se bem que a apropriação privada caracterizadora do modelo capitalista é a dos meios de produção, visto que mesmo nos modelos econômicos socialistas ainda existentes há a propriedade privada dos bens de consumo, o que não chega, em absoluto, a delimitar aquela organização econômica (SILVA NETO, 2001, p. 107).

Venosa (2003, p. 154, v. 5), sobre a história do modelo socialista diz:

O esfacelamento do mundo comunista, com o desaparecimento da União Soviética, retratou o fracasso da experiência do capitalismo do Estado, que buscava a negação da propriedade privada. Contrariava a própria natureza do ser humano; sua vontade inata de ter algo para si. Fora esse modelo, mesmo a filosofia capitalista altera-se em nossa época. O Estado intervém cada vez mais nos meios de produção e na propriedade privada. A intervenção do Estado é fato de extrema importância, sentida com maior ou menor peso por todas as nações. Ou seja, há forte tendência socializante no Estado capitalista. O liberalismo pleno torna-se inviável. Com a economia estatizando-se, o Estado passa de mero fiscal prestador de serviços ao cidadão. Ainda é prematuro prever seus limites e para onde essa intervenção levará. De qualquer forma, ensina a história recente que, se a negação da propriedade privada contraria o anseio inarredável do homem e conduz o Estado ao fracasso, não é com o puro individualismo que serão resolvidos os problemas jurídicos e sociais. A Encíclica Mater et Magistra do Papa João XXIII, de 1961, ensina que a propriedade é um direito natural, mas esse direito deve ser exercido de acordo com a função social, não só em proveito do titular, mas também em benefício da coletividade. Destarte, o Estado não pode omitir-se no ordenamento sociológico da propriedade. Deve fornecer instrumentos jurídicos eficazes para o proprietário defender o que é seu e que é utilizado em seu proveito, de sua família e de seu grupo social. Deve, por outro lado, criar instrumentos legais e eficazes e justos para tornar todo e qualquer bem produtivo e útil. Bem não utilizado ou mal utilizado é constante motivo de inquietação social. A má utilização da terra e do espaço urbano gera violência. $\mathrm{O}$ instituto da desapropriação para finalidade social deve auxiliar a preencher o desiderato da justa utilização dos bens. 
Ademais, a preocupação do civilista (VENOSA, 2003, p. 154, v. 5) é dizer que a propriedade deve respeitar os anseios humanos, dar utilização adequada ao interesse privado com reflexos desse interesse e utilização racional e adequada à função social, em benefício da coletividade. E, nesta perspectiva, o Estado deve dispor de instrumentos, meios adequados à defesa do direito de propriedade.

A propriedade tem contornos individuais, mas a relevância erigida hoje, no mundo capitalista, não tem os fins em si mesmos, antes calcados nos benefícios coletivos, respeito à adequada utilização do imóvel. O Código Civil, no art. 1.228, § $1^{\circ}$, explicita este conteúdo. Esse texto normativo contém interesses coletivos no seu bojo, pois "presentes estão nessas dicções princípios afastados do individualismo histórico que não somente buscam coibir o uso abusivo da propriedade" (VENOSA, 2003, p. 156, v. 5), notada a preocupação do legislador ordinário em inserir a propriedade no contexto de utilização racional da propriedade longe de um individualismo exacerbado ou sobressalente no meio social.

A Constituição Federal de 1934, art. 113, n. 17, modificou o conceito de propriedade descrito no Código Civil de 1916, que era de cunho individualista, a preencher sua moldura para o interesse social ou coletivo, doutrina Bevilaqua (1979, p. 1005, v. 2), sob a vigência do Código Civil de 1916, e esclarece:

\begin{abstract}
A Constituição de 1934, art. 113, n. 17, modificou o conceito de propriedade consignado no Código Civil, aproximando-o mais do exarado no Projeto primitivo. Estatui o citado preceito constitucional: - É garantido o direito de propriedade, que não poderá ser exercido contra o interesse social ou coletivo, na forma que a lei determinar.
\end{abstract}

$\mathrm{O}$ art. 186, da $\mathrm{CF} / 88$, diz que a função social é cumprida quando a propriedade rural atende, simultaneamente, critérios e graus de exigências estabelecidos em lei, os requisitos: $a$ ) aproveitamento racional e adequado; $b$ ) utilização adequada dos recursos naturais e disponíveis e preservação do meio ambiente; $c$ ) observância das disposições que regulam as relações de trabalho; e, $d$ ) exploração que favoreça o bem-estar dos proprietários e dos trabalhadores.

Venosa (2003, p. 156, v. 5), sobre a importância da Constituição Federal de 1988, doutrina:

$\mathrm{O}$ art. $5^{\circ}$ da Constituição de 1988, após garantir o direito de propriedade em seu caput e no inciso XXII, destaque que "a propriedade atenderá a sua função social (XXIII)". O art. 170 da Carta, ao tratar da ordem econômica, dando valor ao trabalho e à livre iniciativa, conforme os ditames da justiça social, garante ao princípio da "função social da propriedade" (inciso III), após referir-se ao princípio da propriedade privada em si mesma (inciso II). 
Ao tratar da política urbana, o legislador constitucional destaca que " $a$ propriedade urbana cumpre sua função social quando atende às exigências fundamentais de ordenação da cidade expressas no plano diretor" (art. 182, $\left.\S 1^{\circ}\right)$.

A propriedade, como se nota, sofre limitações de várias naturezas, seja de ordem constitucional, seja de ordem ordinária, com o Código Civil de 1916 e 2002 em razão do direito de vizinhança. Deve o proprietário se atentar para preservar o meio ambiente, fauna, flora, patrimônio artístico etc, preceitua Venosa (2003, p. 157, v. 5).

Espínola (2002, p. 190-1) diz que a função social, como observa Barassi, tem o pressuposto de confiança recíproca e boa-fé, que integra no moderno conceito de obrigação: “[...] encontra correspondência na função social, implícita no direito de propriedade, no sentido de consideração à solidariedade social, compreendendo os direitos do proprietário e os deveres que lhe são impostos pela política legislativa". Salienta:

É afirmação corrente que a solidariedade social, embora tenha, como conceitua Barassi, a sua expressão sintética no Estado, é, no que diz respeito à disciplina do direito de propriedade, uma satisfação eqüitativa e equilibrada de interesses individuais e de interesses globais da coletividade, "interesses que se deve harmonizar no regime da propriedade privada" (ESPÍNOLA, 2002, p. 191).

E, apresenta a origem misteriosa e indeterminada da fórmula da função social:

\begin{abstract}
Não é supérfluo insistir, observa com razão Barassi, que a fórmula, função social, ainda que misteriosa por sua indeterminação, sempre sintetizou as finalidades superiores ao interesse pessoal do proprietário, como meta ulterior para onde deve convergir a gestão do proprietário com as quais deve ser coordenado o seu interesse.

A função social se deve entender como expressão destinada a disciplinar a atividade, os direitos e deveres do proprietário (ESPÍNOLA, 2002, p. 194).
\end{abstract}

A função social pode ser dividida em função social impulsiva e função social limite. A primeira atribui à lei determinar as medidas que se destinam a considerar os fins sociais na atividade econômica. A segunda considera os aspectos exteriores da forma, ou seja, tem caráter negativo, "[...] como limite exterior que comprime, de modos diferentes e com intensidade diversa a atividade normal do proprietário" (ESPÍNOLA, 2002, p. 195).

A indeterminação contida na fórmula da função social aludida por Barassi (apud ESPÍNOLA, 2002, p. 194), pode ser entendida, conforme ventila Comparato (1996, p. 43), no âmbito das normas constitucionais que trata da matéria: 
De qualquer forma, a conclusão que se pode extrair desse conjunto de normas constitucionais relativas à função social da propriedade é que o Estado exerce um papel decisivo e insubstituível na aplicação normativa. Assim, tanto no plano urbano quanto no rural, o dever de adequada utilização de seus bens em proveito da sociedade supõe a existência de uma política urbana e de uma política agrária, ou seja, um programa de atuação governamental. Um Estado despreocupado com o bem-estar geral da população não tem legitimidade para exigir dos proprietários o cumprimento de sua função social.

Desta forma, conclui-se, do pensamento de Comparato, que o Estado deve ser atuante com um programa sólido a destinar adequadamente um programa para a propriedade, tanto urbana, quanto rural. Deve-se, no entanto, observar no que tange a atividade empresarial, como diz Comparato (1996, p. 43): "Poder-se-á dizer o mesmo em relação ao exercício da atividade empresarial?".

\title{
1.1 FUNÇÃO SOCIAL: CONTEÚDO METAJURÍDICO
}

Esse item, o conceito de função social da propriedade atinge contornos que extrapolam os limites jurídicos, ou seja, atinge contornos de caráter político em detrimento do jurídico, e varia conforme as tendências políticas.

\begin{abstract}
Veja-se, que sob a influência do Princípio da solidariedade Social, introduzido com a Constituição de Weimar de 1919, a idéia de função social correspondia ao dever de empregar os meios de produção no modo mais útil à coletividade. Este "modo mais útil" significava a função de concorrer para uma melhor distribuição da renda; prover mais a ampla assistência possível às classes menos favorecidas e promover a composição entre os interesses dos detentores do poder econômico e aqueles da classe dos trabalhadores (FRANCO, 2008, p. 126).
\end{abstract}

Sob o prisma do fascismo, a ideologia de Benito Mussolini (FRANCO, 2008, p. 127), “[...] a idéia de função social concentrava-se no dever legal de utilizar a propriedade dos meios de produção tendo em vista o interesse nacional, o qual era entendido como o aumento da produtividade da nação e o incremento da produção". Já na União Soviética, a ideologia ali existente era a de que o interesse social da sociedade em sentido estrito deveria coincidir com aquele da economia nacional.

Esta tendência típica dos regimes totalitários é analisada por Sztajn (apud FRANCO, 2008, p. 127):

Retrospecto histórico permite constatar que recorrer à função social é característica de regimes não-democráticos, fazendo com que os interesses nacionais (do governo) se sobrepusessem aos individuais. Outro argumento recorrente para justificar a função social é a perseguição de equilíbrio entre classes sociais, entre o dito poder econômico e os trabalhadores, por exemplo, ou entre aquele e os menos favorecidos. Há ainda quem considere a 
função social como meio para promover a solidariedade entre membros da comunidade, visando ao maior bem-estar geral [...].

Assim, como se mencionou no item 1, o conteúdo do Código Civil de 2002 respeita a regra do regime econômico adotado no Estado da República Federativa do Brasil, salienta Franco (2008, p. 128).

\section{A EMPRESA}

\subsection{TEORIA DA EMPRESA}

Bertoldi e Ribeiro (2006, p. 28), dizem que com o descrédito da teoria dos atos de comércio, modernamente se tem discutido a criação de um critério científico para a caracterização da matéria comercial que atenda as demandas e anseios do atual estágio do desenvolvimento econômico.

Em 1942, em Itália, o Código Civil deu passo importante na construção de uma teoria eficaz em dar contorno e limites ao direito comercial. É mudança de foco na abordagem, pois surge novo sistema de regulação das atividades econômicas dos particulares, ventila Coelho (2003, p. 8).

A ambientação de onde e quando surgiu a teoria da empresa deve ser analisada e descrita para melhor ter a conotação jurídica do que ela prega e os fins nela contidos. Ao dizer que esta teoria surgiu na época da Itália fascista e sob o manto de regime totalitário, tendo alcançado entendimento de Asquini (COELHO, 2003, p. 9) e aponta que um dos perfis da empresa era o corporativo, expressava a comunhão dos interesses do empresário e trabalhadores.

O direito brasileiro acompanha o direito italiano, de unificação da matéria civil e comercial. Mesmo antes da edição do atual Código Civil, que adota a teoria da empresa, ventila Bertoldi e Ribeiro (2006, p. 29).

Coelho (2003, p. 23, v. 1) diz que, o Brasil, paulatinamente, por ser de tradição romanística, aproxima-se do direito italiano, isto é, “[...] do estabelecimento de um regime geral de disciplina privada da atividade econômica, que apenas não alcança certas modalidades de importância marginal". Pode-se encontrar em diversos diplomas legais, por exemplo, a teoria da empresa, tais como: Lei n. 8.078/90, art. $3^{\circ}$; Lei n. 6.404/76, art. $2^{\circ}, \S 1^{\text {o }}$; e, Lei n. 8.934/94, art. $2^{\circ}$ (BERTOLDI; RIBEIRO, 2006. p. 29). 


\subsection{CONCEITO DE EMPRESA}

O direito brasileiro não define, claramente, o que seja empresa, mas fornece definição indireta e subjetiva, através do conceito de empresário, não resta dúvida de que o direito brasileiro adota definitivamente a teoria da empresa (BERTOLDI; RIBEIRO, 2006, p. 30). Há, no entanto, duas distinções do conceito de empresa, uma noção econômica, outra jurídica. Doria (2000, p. 45, v. 1), diz que é campo tormentoso e inacabado na doutrina a conceituação de empresa.

\subsubsection{NOÇÃO ECONÔMICA DO CONCEITO DE EMPRESA}

Hentz (1998, p. 55) ventila que a empresa é o ente responsável pela satisfação das necessidades coletivas, através do exercício de atividades produtivas, intermediação e prestação de serviços. Tal panorama pode ser notado na evolução das relações pessoais, as necessidades destas, o progresso tecnológico.

Estas relações podem ser sentidas na extrapolação das fronteiras do país, a atingir relevo transnacional, seja pela proliferação de empresas transnacionais, com a prestação de serviços, enfim, atividades que atendam as necessidades das pessoas, sejam elas físicas ou jurídicas, ou mesmo as empresas públicas ${ }^{3}$, mistas.

Coelho (2003, p. 47, v. 1) salienta que esse processo de integração econômica regional força os acordos comerciais, desenvolve as organizações e faz com que os acordos comerciais os participantes assumam reciprocamente o compromisso de eliminar as barreiras tarifárias existentes nas suas fronteiras; ou seja, as mercadorias produzidas em cada país participante do processo integrativo têm livre circulação nos demais, e salienta: “As barreiras tarifárias permanecem apenas em relação aos produtos importados por empresas sediadas em qualquer um dos países participantes, para a comercialização nos outros".

E, nesta linha, Hentz (1998, p. 56) delineia o conceito econômico de empresa:

O conceito econômico de empresa resulta de observações de Giuseppe Ferri. A produção de bens e serviços para o mercado é fruto de uma atividade especializada e profissional, por meio de organismos econômicos permanente

\footnotetext{
3 Rolim (2004, p. 47) sobre as atividades dos serviços governamentais, diz: "Alguns autores preferem denominar serviços governamentais as atividades econômicas prestadas pelas empresas públicas, sociedades de economia e suas subsidiárias, criadas pelo Estados nos termos do art. 173 da Constituição Federal. [...] De uma forma ou de outra, podemos citar como exemplo de entidades que executam atividades ou serviços governamentais, entre outros, todas as sociedades de economia mista, que, geralmente, tem a forma de sociedade anônima".
} 
nela predispostos. Esses organismos econômicos, voltados à organização dos fatores de produção e que se propõem à satisfação das necessidades alheias, são as empresas. O papel da empresa em relação aos fatores da produção resulta da noção que, no século passado, os economistas clássicos tinham de organização econômica. A empresa, como organismo econômico, se assenta sobre uma organização fundada em princípios técnicos e leis econômicas. Apresenta-se como uma combinação de elementos pessoais e reais, colocados em função de um resultado econômico, e realizada em vista do intento especulativo de uma pessoa.

Não é atividade desenfreada ou por acaso desempenhada por agente econômico. É atividade especializada e profissional que se utiliza dos mecanismos e instrumentos econômicos permanentes nela predispostos. Requião (2003, p. 49-50, v. 1) ventila o panorama que centra o conceito econômico debatido:

\begin{abstract}
Os economistas clássicos, no século XIX, haviam observado as organizações econômicas destinadas à produção, tendo J. B. Say exaltado a figura do empresário, mostrando que é ele "o eixo a um tempo da produção e da repartição, aquele que adapta os recursos sociais às necessidades sociais e que remunera os colaboradores da obra cujo chefe é". Na reação socialista dos reformadores, Saint-Simon colocou no centro da sociedade a figura dos grandes empresários. Desde então, a Economia Política passou a considerar, com a relevância devida, o papel da empresa, como organização dos fatores da produção.
\end{abstract}

Manifesta-se a empresa como “[...] uma organização técnico-econômica, ordenando o emprego de capital e trabalho para a exploração, com fins lucrativos, de uma atividade produtiva", leciona Campinho (2006, p. 11), e aduz que "nasce a empresa a partir do início da atividade economicamente organizada, sob o comando do empresário".

\title{
2.2.2 NOÇÃO E CONCEITO JURÍDICO DA EMPRESA
}

Como assinalado (item 2.2) e dito por Doria (2000, p. 45, v. 1), a conceituação jurídica da empresa é tormentoso. Hentz (1998, p. 56) diz que o conceito jurídico de empresa se assenta no conceito econômico, Requião (2003, p. 50, v. 1) igualmente. Doria (2000, p. 45, v. 1), diz:

Justapondo o conceito econômico ao jurídico, Vivante entende a empresa como "um organismo econômico que põe em jogo os elementos necessários para obter um certo produto destinado à troca, com risco do empresário". Para ele, "o Direito Comercial faz seu este conceito econômico".

Para Hentz (1998, p. 57), na concepção jurídico-comercial, empresa significa atividade exercida pelo empresário, “[...] do que resulta a importância desse no campo 
do direito comercial". Ferri (apud REQUIÃO, 2003, p. 51, v. 1) apresenta ângulos expressivos da empresa, dos quais interessa ao direito:

a) A empresa como expressão da atividade do empresário. A atividade do empresário está sujeita a normas precisas, que subordinam o exercício da empresa a determinadas condições ou pressupostos ou o titulam com particulares garantias. São as disposições legais que se referem à empresa comercial, como o seu registro e condições de funcionamento.

b) A empresa como idéia criadora, a que a lei concede tutela. São as normas legais de repressão à concorrência desleal, proteção à propriedade imaterial (nome comercial, marcas, patentes etc.).

c) Como um complexo de bens, que forma o estabelecimento comercial, regulando a sua proteção (ponto comercial), e a transparência de sua propriedade.

d) As relações com os dependentes, segundo princípios hierárquicos e disciplinares nas relações de emprego, matéria que hoje se desvinculou do direito comercial para se integrar no direito do trabalho.

E, Requião (2003, p. 51, v. 1) alude que, segundo os ensinamentos de Ferri, a disciplina jurídica da empresa é a disciplina da atividade do empresário, e a tutela jurídica da empresa é a tutela jurídica dessa atividade, assim, na acepção jurídica, “[...] significa uma atividade exercida pelo empresário. Disso decorre inevitavelmente que avulta no campo jurídico a proeminente figura do empresário".

Contudo, o Código Civil de 2002, no art. 966, conceitua empresário, mas não a empresa, que adotou o critério italiano e não a conceituou. Para o Código Civil, empresário é quem exerce profissionalmente atividade econômica organizada para a produção ou a circulação de bens ou de serviços, ventila Requião (2003, p. 58, v. $1)$.

\subsection{DISTINÇÃO ENTRE EMPRESA E SOCIEDADE}

A principal distinção entre empresa e sociedade empresária, e mais didática, no dizer de Requião (2003, p. 60, v. 1), é a que vê na sociedade o sujeito de direito, e na empresa, mesmo como exercício de atividade, o objeto de direito. Sociedade empresária e não sociedade empresarial, isto é, de empresários, porque é a própria pessoa jurídica a empresária (COELHO, 2003, p. 64, v. 1).

A sociedade, constituída conforme as solenidades legais, adquire categoria de pessoa jurídica, tornando-se capaz de direitos e obrigações, a sociedade é empresária, jamais empresa (REQUIÃO, 2003, p. 60, v. 1); a sociedade empresária exercita a atividade produtiva, que pode ser exercida pelo particular (HENTZ, 1998, p. 63). É a sociedade, como empresário, que irá exercitar a atividade produtiva. 
Outra distinção é a atividade individual que pode ser exercida pela empresa, na atividade individual, de pessoa natural. É a empresa individual. Ela não se pressupõe uma sociedade empresária (REQUIÃO, 2003, p. 61, v. 1).

Pode haver sociedade empresária sem empresa, quando duas pessoas formam o contrato social e o registram na Junta Comercial, a formar uma sociedade, e enquanto estiver inativa, ela não surge (REQUIÃO, 2003, p. 61, v. 1).

\section{ATIVIDADE EMPRESARIAL}

\subsection{NOÇÕES GERAIS}

Atividade, em direito, designa uma série de atos unificados em razão do mesmo objetivo global. O regime jurídico da atividade é diverso dos simples atos isolados, ventila Comparato (1996, p. 41). Este autor analisa o conceito de função e aplica-o ao de atividade, e diz:

Se analisarmos mais de perto esse conceito abstrato de função, em suas múltiplas espécies, veremos que o escopo perseguido pelo agente é sempre o interesse alheio, e não o próprio do titular do poder. O desenvolvimento da atividade e, portanto, um dever, mais exatamente, um poder-dever; e isto, não no sentido negativo, de respeito a certos limites estabelecidos em lei para o exercício da atividade, mas na acepção positiva, de algo que deve ser feito ou cumprido.

Comparato (1996, p. 41), em nota de rodapé n. 9, sobre a importância do conceito de atividade empresarial, diz:

O conceito de atividade empresarial constitui hoje, como sabido, o fulcro de todo o sistema do direito comercial, assim como o de atividade administrativa pode ser tomado como conceito nuclear do direito administrativo.

Falar em atividade empresarial é falar em atividade econômica unitariamente estruturada para a produção ou a circulação de bens ou serviços, como alude Reale (apud WALD, 2005, p. 30, v. 14). "É da ação intencional (elemento abstrato) do empresário em exercitar a atividade econômica que surge a empresa”, reforça Requião (2003, p. 59, v. 1).

O empresário organiza a atividade, utilizando-se dos bens e do instrumento humano, eis que surge, assim, a organização. Por isso diz-se que é um complexo de 
bens e um conjunto de pessoal inativo, se bastar apenas na organização, sem atuação. No instante em que produz, tem-se a atividade, leciona Requião (2003, p. 59, v. 1).

Na caracterização da empresa deve existir o exercício de atividade econômica (produtiva), diz Wald (2005, p. 41-2, v. 14):

[...] de uma atividade que tenha por fim a criação ou circulação de riquezas, bens ou serviços. Além da criação de riquezas, a idéia da empresa está relacionada com o princípio da economicidade, ou seja, com o desenvolvimento de uma atividade capaz de cobrir os próprios custos, ainda que não existam finalidades lucrativas.

A criação de riquezas como núcleo da atividade produtiva tem outra face, ser capaz de gerir a si própria (atividade produtiva) e, não é só, como dizem Jaeger e Denozza (apud WALD, 2005, p. 42, v. 14):

[...] afirmam ser relevante verificar o modo como a atividade é desenvolvida e o escopo que pretende atingir. Para esclarecer a posição tomada, os autores trazem os seguintes exemplos, que demonstram como atividade pode ter o mesmo fim e se apresentar em modalidades diversas: I) transporte público gratuito ou com fins lucrativos e II) escola de línguas visando a obtenção de lucros ou simplesmente para difundir a cultura de determinado país, subvencionada pelo seu governo. Concluem que, no caso do transporte público gratuito e da difusão não remunerada da cultura, pode não haver empresa, pois os recursos utilizados não advêm do próprio desenvolvimento da atividade, mas sim das taxas públicas, não se caracterizando a atividade econômica de empresário.

É, sem embargos, olhar o objeto social. Não pode ser comprometida a função social pela má conduta do empresário. A esse respeito, pode-se inserir a função social e a atividade empresarial em um instituto jurídico para notar o comportamento que ela adquirirá, com estribo na lição de Wald (2005, p. 42, v. 14):

\footnotetext{
Diante da análise da origem do direito de retirada, inserido no Código Civil de 2002, há que se indagar se é possível o seu exercício indiscriminado, uma vez que a retirada de um sócio muitas vezes pode acarretar na dissolução da sociedade, conforme, aliás, previsto e permitido pelo parágrafo único do art. 1.029 , prejudicando, portanto, a sua função social. Melhor dizendo, a retirada de um sócio pode acabar por comprometer ou impedir a empresa de cumprir o seu objeto social, inclusive sacrificando direito de empregados e de outras pessoas que dependam direta ou indiretamente da atividade econômica desenvolvida pela sociedade (fornecedores, adquirentes de matéria prima etc.).
}

Com a crescente modernização das relações entre as sociedades, a incessante busca pelo lucro, o progresso notado, tanto no aspecto social, quanto no econômico, 
força ao empresário buscar aliados. Muito embora haja a crescente proliferação de empresários individuais, pessoa física, o qual deverá contar com capacidade para o exercício da ocupação mercantil (art. 972, do CC), há uma enorme onda de coligações entre pessoas jurídicas. Ou seja, o crescente número de empresas que se formam para prestar serviços, compor conglomerados empresariais.

E, é neste terreno que a função social deve ser notada. A atividade empresarial não pode ficar adstrita ao simples empresário, ao empresário individual, pessoa física. Tenta-se, com isso, olhar as conseqüências jurídicas ocorridas no campo social, a crescente busca pelo lucro força as empresas a buscarem aliadas, outras pessoas jurídicas para se unirem e fortalecerem, seja na estrutura do seu contrato social, seja na prestação de bem e serviços.

É olhar, portanto, no perfil do empresário do mundo moderno e exigente, salienta Wald (2005, p. 15), e com apoio em Dunant, salienta a importância do fortalecimento e união entre o industrial e o comerciante.

\subsection{ATIVIDADE: ATOS DE ADMINISTRAÇÃO}

Especificamente atividade compreende um conjunto de atos, quando em movimento. “[...] Porém, não é qualquer conjunto de atos. Somente quando os atos são coordenados, conseqüentes e tendentes a um mesmo objetivo é que se pode visualizar a atividade", doutrina Franco (2004, p. 43, v. 1).

Os atos podem ser ordinários e extraordinários. Ordinários são aqueles adequados à realização da finalidade visada pela atividade. Extraordinários quando o ato de gestão é irregular (FRANCO, 2004, p. 44, v. 1).

\subsection{DISCIPLINA JURÍDICA DA ATIVIDADE}

A doutrina diz que sujeito da atividade é quem a exercer, a pessoa física ou jurídica titular de direitos e obrigações. Quando se trata de atividade, não se diz capacidade, mas habilitação. A atividade não é nula ou anulável, mas lícita ou ilícita, regular ou irregular, conforme ela se adapte ao ordenamento jurídico. Os atos singulares que compõem a atividade, encarados como atos jurídicos, serão nulos ou anuláveis, quando submetidos às formalidades exigidas por lei para a constituição do ato jurídico lícito. Para estes, exige-se a capacidade (FRANCO, 2004, p. 46, v. 1). 
A valoração da atividade é feita de forma isolada dos atos que a compõem, a disciplina jurídica dos atos singulares está submetida ao direito privado; a da atividade, ao direito público. Os atos jurídicos serão perfeitos, nulos, anuláveis ou ineficazes, a atividade será lícita, ilícita, regular ou irregular (FRANCO, 2004, p. 46-7, v. 1).

\subsection{ATIVIDADE ECONÔMICA E ATIVIDADE ECONÔMICA EMPRESARIAL}

Toda atividade empresarial é econômica, mas não é toda atividade econômica ${ }^{4}$ que é empresarial, somente consideradas as atividades econômicas lícitas. E, não basta que seja lícita. A atividade deve ser regular, a desenvolver-se conforme exigências administrativas, Franco (2004, p. 47, v. 1).

Portanto, as características da atividade podem ser descritas como lícitas, regular, exercida em nome próprio, com o fito de lucro, sob o aspecto de critério de economicidade, e dotada de uma certa organização de pessoas e meios, doutrina Franco (2004, p. 48, v. 1).

\section{FUNÇÃO SOCIAL - ORIENTAÇÃO DOUTRINÁRIA}

\subsection{NOÇÃO, CONCEITO, ESTRUTURA}

O substantivo functio, na língua matriz, é derivado do verbo depoente fungor (functus sum, fungi), cujo significado primigênio é cumprir algo ou desempenhar-se de um dever ou uma tarefa. A ligação do verbo com a noção de múnus público remonta aos clássicos latinos (COMPARATO, 1996, p. 40). Cícero fala em munus aedilicium, e na De Re Publica, em imperii consulatusque munus fungendi (COMPARATO, 1996, p. 40).

Há funções exercidas no interesse de uma pessoa ou de pessoas determinadas e funções que devem ser desempenhadas em benefício da coletividade. Nesta última hipótese é que se pode falar em função social, salienta Comparato (1996, p. 41).

O termo função social foi se transferindo pelas ciências sociais. Surgiu na filosofia e, conseqüentemente, passou para o direito, surgindo como função social da

\footnotetext{
$4 \quad$ Rolim (2004, p. 45), diz: "É de se ressaltar, entretanto, que nada impede o Estado de instituir uma fundação pública ou mesmo uma sociedade de economia mista com a natureza jurídica de 'direito público', casos em que, consequentemente, estará prestando um 'serviço público stricto sensu ou propriamente dito', e não explorando uma 'atividade econômica'. Tal procedimento, entretanto, é exceção no ordenamento jurídico brasileiro".
} 
propriedade. "O conceito de função social teria sido formulado pela primeira vez por São Tomás de Aquino, quando afirmou que os bens apropriados individualmente teriam um destino comum, que o homem deveria respeitar" (TOMASEVICIUS FILHO, 2003, p. 34).

Assim, Comte formulou seu conceito de função social como dever de agir (TOMASEVICIUS FILHO, 2003, p. 34), na seguinte fórmula:

\begin{abstract}
Em todo estado normal da humanidade, todo cidadão, qualquer que seja, constitui realmente um funcionário público, cujas atribuições, mais ou menos definidas, determinam, por sua vez, obrigações e pretensões. Este princípio universal deve certamente estender-se até a propriedade, na qual o positivismo vê, acima de tudo, uma indispensável função social destinada a formar e a administrar os capitais, com os quais cada geração prepara os trabalhos da seguinte.
\end{abstract}

Na explicação de Tomasevicius Filho (2003, p. 34), a visão de Comte havia o binômio ordem e progresso, sendo este condicionante daquele. Dessa forma, os seres humanos eram vistos como funcionários, que deveriam agir conforme essa ordem imposta. Assim, cada ser humano deve trabalhar em função da ordem social, agindo sem liberdade, mas sim em benefício ou em função da sociedade.

\title{
4.1.1 MODERNAS TEORIAS SOBRE A FUNÇÃO SOCIAL
}

A orientação doutrinária ao qual Tomasevicius Filho (2003, p. 37) alude, na moderna idéia sobre a função social, é a busca pelas respostas nas contradições encontradas (item 4.1.2). A sistematização relevante de Comparato (apud TOMASEVICIUS FILHO, 2003, p. 37), tem importante divisor de águas, e ventila:

Comparato chama a atenção para o fato de que a doutrina tradicional faz a distinção entre bens móveis e imóveis. Esta distinção teria origem medieval e refletia a organização vigente na Europa naquela época, em que os bens imóveis conferiam poder político. A classificação mais importante atualmente, segundo Comparato, é a de bens de consumo e bens de produção, que se finda não na sua natureza ou consistência, mas na destinação que se lhes dê. Apenas os bens de produção deveriam exercer uma função social, que consiste no poder-dever de vincular a coisa a um objetivo determinado pelo interesse coletivo.

Essa concepção é mais razoável. Os bens de produção são as fontes de riqueza de uma sociedade, enquanto os bens de consumo são destinados para o uso do seu proprietário. Não há como exigir desses bens o atendimento de função social. Não produzem riquezas. Além disso, segundo a psicologia moderna, os bens de uma pessoa constituem a sua identidade. 
Para Grau (TOMASEVICIUS FILHO, 2003, p. 37), a função social da propriedade coincide com a função social da empresa:

\begin{abstract}
Aí, incidindo pronunciadamente sobre a propriedade dos bens de produção, é que se realiza a função social da propriedade. Por isso se expressa, em regra, já que os bens de produção são postos em dinamismo, no capitalismo, em regime de empresa, como função social da empresa.
\end{abstract}

Assim, este posicionamento coloca a função social da propriedade e da empresa em pé de igualdade, comparando-as e dando a mesma funcionalidade. Nota-se que antes foi dada uma concepção econômica, aqui, é dada uma concepção de utilidade ${ }^{5}$, a propriedade e/ou empresa está imersa no dinamismo do sistema econômico, e não puramente com o sistema econômico. É bem de produção, e não um fim em si mesmo.

\title{
5 FUNÇÃO SOCIAL DA EMPRESA
}

Descreve-se a doutrina de Franco (2008, p. 129), que está estrutura de forma a colocar a empresa no âmbito do mercado ou economia de planificação global.

\subsection{POSICIONAMENTO DOUTRINÁRIO DE FRANCO}

Há dissenso quando se trata da função e cumprimento social, da função social da empresa, notadamente quando diz respeito à chamada funcionalização da empresa, quando pode se realizar independentemente da intervenção estatal, e outros sustentam a necessidade de um controle social (público) cerrado sobre a atividade econômica (FRANCO, 2008, p. 129).

Franco alude a dois posicionamentos doutrinários, de Gallo e Iudica. Para o primeiro, a proposta é a da funcionalização da atividade econômica em regime de livre iniciativa, onde se afasta qualquer possibilidade de supervisão ou ingerência estatal. Portanto, Gallo (apud FRANCO, 2008, p. 129) assinala à função social um duplo dever de agir:

1) O de colaborar com a realização do bem comum, conforme as necessidades detectadas no meio próximo àquele em que tem lugar o exercício da atividade econômica;

2) Prover ao que chama de "responsabilidade social interna", a qual consistiria em atender às necessidades dos que trabalham na empresa, promovendo o seu aperfeiçoamento integral, isto é, físico, técnico e moral, além de permitir uma maior participação na atividade empresarial.

5 Pragmatismo. Pode ser analisado o princípio de utilidade proposto por Bentham (apud COLLINSON, 2004, p. 163), doutrina esta inspirada na frase "a maior felicidade para o maior número". Para um estudo aprofundado das teorias pragmáticas, cf. SOUZA (2005, p. 229-302). 
Nota-se que no primeiro momento, a realização do bem comum é atividade extra-empresa, com reflexos no social; e, no segundo momento, é o ambiente interno, intra-empresa. A união do extra e intra-empresa satisfazem a necessidade do cumprimento da função social da empresa.

$\mathrm{O}$ meio onde se exerce a atividade empresarial deve proporcionar um espaço para que se busque a satisfação de necessidades reais, efetivas, pautadas pelos princípios da Solidariedade e da Subsidiariedade, o que encontra expressão no equilíbrio entre o interesse econômico e o interesse social, salienta Franco (2008, p. 129).

Já para Iudica, a sua teoria situa-se no extremo oposto, pois sustenta que o conjunto, se somada as diferentes tendências, leva à proposição de um controle social acentuado do Estado sobre a atividade econômica; afinal, a tutela constitucional da liberdade de iniciativa econômica em quase nada garante a autonomia do empresário (FRANCO, 2008, p. 130).

E, mais a frente, Franco (2008, p. 130), com base nas teses de Iudica, diz:

\begin{abstract}
Conforme a tese, o que deve ser entendido por utilidade social é tarefa de definição do Poder Público, o qual deverá ditar o comportamento a que as empresas deverão se ater para a realização dos fins considerados de "utilidade social". E o Estado, nessa tarefa, pode impor, em nome da funcionalização e da persecução de fins gerais, quaisquer comportamentos que julgue adequados, pois as normas constitucionais destinadas à tutela da atividade econômica, dada sua excessiva generalidade, não garantem o empresário contra a imposição de vínculos, incompatíveis com a sua intenção lucrativa, com a sua permanência no mercado e sequer lhe assegura um núcleo mínimo de autonomia.
\end{abstract}

$\mathrm{O}$ ponto demonstra que o interesse social tem prevalência em detrimento e mitigação, exacerbadamente, quando contrastada ao interesse empresarial. Deve, nesta tese, o interesse empresarial permanecer refém do que o Poder Público entende por utilidade social.

\title{
5.1.1 FUNÇÃO SOCIAL: DEVER DE AGIR EM ATENÇÃO AOS INTERESSES COLETIVOS
}

Novamente, Franco (2008, p. 131) conclui que de forma muito genérica é que se pode delimitar, controle semântico, do significado da função social: “A expressão é por demais ampla para que se lhe possa determinar o conteúdo mediante a atribuição taxativa de determinados comportamentos ao empresário", e ventila: 
No mais, se o nomem "função" encerra a conotação de um dever de agir no interesse de outrem que não no daquele a quem se atribui a função, o qualificativo social é suficiente para indicar o sujeito passivo, no interesse de quem deve atuar a companhia, isto é, a coletividade.

Assim, o dever de prestar atenção aos interesses coletivos está inserido em atuar no interesse de outrem e não na atribuição da função. É um olhar nas necessidades do outro em detrimento do lugar onde se está. Creia-se, portanto, que a função social da empresa deve estar além dos interesses empresários, mas que também deva conter estes interesses no conceito.

\section{CONCLUSÃO}

Conclui-se, portanto, que a função social da empresa tem significado e relevo importantíssimo na vida, seja no contexto econômico, com o fomento, impulso, desenvolvimento, seja no contexto social, com a união de pessoas físicas, agrupamento social com fim de produção ou prestação de serviços, seja no jurídico, o fortalecimento de vínculos a buscarem as formas solenes e legais prescritas.

O movimento sobre a análise que deve ser apreendida encontra respaldo no ponto doutrinário de Gallo (apud FRANCO, 2008, p. 129), descrito no item 5.1, onde assinala que a função social tem/adquire duplo dever de agir. Esse duplo dever de agir é: o de colaborar com a realização do bem comum, com a efetiva prática de satisfazer as necessidades do meio onde a atividade é desenvolvida; e, no âmbito interno da empresa, com a chamada "responsabilidade social interna", com a satisfação das necessidades dos que trabalham na empresa, a promover o aperfeiçoamento integral do substrato humano e, também, da maior e efetiva participação da atividade empresarial.

O preenchimento da função social da empresa, desta forma, é muito mais que o simples cumprimento da função social da propriedade e da perfeita atividade empresarial. Observa-se o item 1, ao final, quando Comparato (1996, p. 43), diz "Poderse-á dizer o mesmo em relação ao exercício da atividade empresarial?", ou seja, diz que para a realização da função social da propriedade depende dos programas públicos na efetivação desta função. E que para o exercício da atividade empresarial poder-se-á dizer o mesmo, interroga ele.

Pensar como Comparato (1996, p. 43) é dar conotação puramente normativa ou programática do Poder Público. Os fins das normas não são tidos em si e por si mesmos. 
Há de se observar o conjunto. O ordenamento jurídico deve ser posto no ordenamento social, onde a esfera é mais abrangente e as condutas estão a se desenvolver.

O proposto por Franco (2008, p. 126), descrito no item 1.1, onde a função social da propriedade adquire contornos e ao seu conteúdo a ser preenchido com valores metajurídicos, ou seja, diverso dos fundamentos estampados no bojo normativo, a proporcionar que a leitura dos institutos em comento deve ser feita de forma a extrapolar as normas jurídicas e, assim, notar o programa político desenvolvido pelos governantes no âmbito político em detrimento do jurídico. Também não deve prevalecer.

A conduta da atividade empresarial atinge contornos no meio ambiente. Conforme a doutrina de Gallo (apud FRANCO, 2008, p. 129), já ventilado, é a mais adequada a preencher os contornos da função social da empresa, a justificar que as condutas nos ambientes extra e intra da empresa, beneficiam, tanto o contexto social, quanto os interesses empresariais, o todo.

Gallo (apud FRANCO, 2008, p. 129-30) salienta e elenca que o empresário deve ter cuidado na escolha dos produtos e serviços prestados à coletividade, optar pela instalação dos meios de publicidade, dar atenção na qualidade dos produtos e o dever de garantir a autocontinuidade e a expansão da empresa. Ora, estas condutas descritas não são fundamentos jurídicos. São fundamentos causais, notados no mundo da natureza; e não no mundo da cultura, do construído, do mundo das normas.

O mundo não se resume nas normas, e a função social da empresa demonstra isso, a atitude, a atividade a ser desempenhada para que se preencha a função social está além dos preceitos do ordenamento jurídico.

Deste modo, a contribuição que se espera alcançar: o debate e a construção dos institutos jurídicos, sempre a evolução do direito a desembocar no mundo dos fatos, e, de outro modo, o inverso é mais verdadeiro e útil, sem afastar a segurança jurídica.

Esse é o desafio e a prospecção do que vem a ser a função social da empresa a contrastar com a função social da propriedade e os necessários embates entre o metajurídico e o jurídico, os axiomas e os valores sociais, a conciliação entre o dever ser e o mundo empírico.

Com isso, os direitos reais deverão ter enfoque diferenciado, e novo conceito deve ser pensado à luz da atividade e atuação do empresário na empresa. Tendo em vista que o Código Civil foi elaborado calcado em conceitos indeterminados, vagos, que 
deverão ser preenchidos com regras da experiência, valores, ética, a realçar as relações sociais.

\section{REFERÊNCIAS}

BENTHAM, J. Teoria das penas legais e tratados dos sofismas políticos. Leme: Edijur, 2002.

BERGEL, J. L. Teoria geral do direito. Tradução de Maria Ermantina Galvão. São Paulo: Martins Fontes, 2003.

BERTOLDI, M. M.; RIBEIRO, M. C. P. Curso avançado de direito comercial. 3 ed. São Paulo: Revista dos tribunais, 2006.

BEVILAQUA, C. Código Civil dos Estados Unidos do Brasil. Ed. Histórica. Rio de Janeiro: Rio, 1979. v. 2.

BOBBIO, N. Teoria da norma jurídica. Tradução de Fernando Pavan Baptista e Ariani Bueno Sudatti. Bauru: Edipro, 2001.

CAMPINHO, S. O direito de empresa à luz do novo Código Civil. 7 ed. Rio de Janeiro: Renovar, 2006.

COELHO, F. U. Curso de direito comercial. 7 ed. São Paulo: Saraiva, 2003. v. 1.

Manual de direito comercial. 14 ed. São Paulo: Saraiva, 2003.

COLLINSON, D. 50 grandes filósofos. Tradução de Maurício Waldman e Bia Costa. São Paulo: Contexto, 2004.

COMPARATO, F. K. Estado, empresa e função social. Revista dos Tribunais. Ano 85, n. 732 , out. -1996 .

COSTA, M. L. da. A propriedade na doutrina de Duguit (exposição e crítica). Revista dos Tribunais. Ano 90, n. 791, set.-2001.

DORIA, D. Curso de direito comercial. 14 ed. São Paulo: Saraiva, 2000. v. 1.

ESPÍNOLA, E. Posse, propriedade, compropriedade ou condomínio, direitos autorais. Campinas: Bookseller, 2002.

FRANCO, V. H. de M. A função social da empresa. Revista do Advogado. ASSOCIAÇÃO DOS ADVOGADOS DE SÃO PAULO - AASP. Ano XXVIII, n. 96, mar.-2008.

Manual de direito comercial. 2 ed. São Paulo: Revista dos Tribunais, 2004. v. 1. 
HENTZ, L. A. S. Direito empresarial: bases do direito empresarial empresa e estabelecimento empresário: direitos e deveres sociedades empresariais. Leme: Editora de Direito, 1998.

MONTEIRO, W. de B. Curso de direito civil: direito das coisas. 5 ed. São Paulo: Saraiva, 1963. v. 3.

REQUIÃO, R. Curso de direito comercial. 25 ed. São Paulo: Saraiva, 2003. v. 1.

RIBEIRO, M. C. P.; BERTOLDI, M. M. Curso avançado de direito comercial. 3 ed. São Paulo: Revista dos tribunais, 2006.

ROLIM, L. A. A administração indireta, as concessionárias e permissionárias em juízo. São Paulo: Revista dos Tribunais, 2004.

SILVA NETO, M. J. Direito constitucional econômico. São Paulo: LTr, 2001.

SOUZA, L. S. F. Abuso de direito processual: uma teoria pragmática. São Paulo: Revista dos Tribunais, 2005.

TAVARES, J. Teoria do injusto penal. 3 ed. Del Rey: Belo Horizonte, 2003.

TOMASEVICIUS FILHO, E. A função social da empresa. Revista dos Tribunais. Ano 92, n. 810, abr.-2003.

VENOSA, S. de S. Direito Civil: direitos reais. 3 ed. São Paulo: Atlas, 2003. v. 5.

WALD, A. Comentários ao novo Código Civil: do direito da empresa. Sálvio de Figueiredo Teixeira (Cood.). Rio de Janeiro: Forense, 2005. v. 14.

A empresa no terceiro milênio. WALD, A; FONSECA, R. G. da. (Coord.). A empresa no terceiro milênio: aspectos jurídicos. São Paulo: Juarez de Oliveira, 2005. 
